Dariusz Tabor CR, Średniowieczne drzwi brąowe i ich cykle obrazowe jako wyraz liturgii: analiza wybranych przykładów, w: Przestrzeń liturgiczna, red. Adelajda Sielepin CHR, Jarosław Superson SAC, Kraków 2019, s. 101-123.

DOI: http://dx.doi.org/10.15633/9788374387828.06

Dariusz Tabor CR

Uniwersytet Papieski Jana Pawla II w Krakowie

\title{
Średniowieczne drzwi brązowe i ich cykle obrazowe jako wyraz liturgii: analiza wybranych przykładów
}

Brązowe drzwi europejskie są tematem fascynującym i rodzącym sporo pytań. Były one przedmiotem badań. Na temat dwóch zabytków polskich - drzwi z Płocka i drzwi z Gniezna istnieje bogata literatura przedmiotu. Drzwi Gnieźnieńskie były już badane od początku lat 50. XX wieku. Badania te zaowocowały zbiorem tekstów autorstwa m.in. Zofii Budkowej, Aleksandra Gieysztora, Lecha Kalinowskiego, Zdzisława Kępińskiego, Mariana Morelowskiego i Sta-

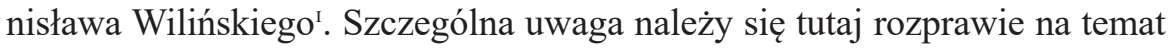
treści Drzwi Gnieźnieńskich autorstwa Lecha Kalinowskiego. Jest to dogłębne studium ikonologiczne przedstawień zarówno kwater, jak i bordiury oraz synteza ogólnego, całościowego przeslania zabytku². Ten znamienity badacz nie jest jedynym, który zagłębiał się w problematykę treści Drzwi Gnieźnieńskich. Wielu historyków sztuki wniosło również znaczący wkład w poznanie tego dzieła ${ }^{3}$.

I Drzwi Gnieźnieńskie, t. I-3, red. M. Walicki, Wrocław I956-I959 (W tomie I z roku I956 m.in.: A. Gieysztor, Drzwi Gnieźnieńskie jako wyraz polskiej świadomości narodowościowej XII wieku, s. I-I9; J. Karwasińska, Drzwi Gnieźnieńskie a rozwój legendy o biskupie Wojciechu, s. 20-4I; M. Morelowski, Drzwi Gnieźnieńskie, ich związki ze sztuka obca a problem rodzimości, s. 42-I00; S. Wiliński, Nad monogramem Drzwi Gnieźnieńskich, s. IOI-I23; Z. Kępiński, Symbolika Drzwi Gnieźnieńskich, s. I6I-38I).

2 L. Kalinowski, Treści ideowe i estetyczne Drzwi Gnieźnieńskich, w: L. Kalinowski, Speculum artis: treści dzieła sztuki średniowiecza i renesansu, Warszawa 1989, s. 227-378; pierwsza publikacja tegoż artykułu w: Drzwi Gnieźnieńskie, dz. cyt., t. I, s. 7-I6o.

3 Por. S. Mossakowski, La Porte de bronze de Gniezno et la „Chronique polonaise” de maître Vincent, „Polish Art Studies” 2 (I980), S. II-29; J. S. Pasierb, Le programme icono- 
W 1982 roku ukazała się praca zbiorowa - kolekcja artykułów poświęconych Drzwiom Płockim ${ }^{4}$. Zawierają one cenne rezultaty badań. Badania nad Drzwiami Płockimi prowadził Ryszard Knapiński. Autor ten sformułował pogląd, że chrystologiczne sceny drzwi były inspirowane apostolskim wyznaniem wiary i są wyrazem jego artykułów. Zidentyfikował on też stylistyczne jakości pochodzącego z Płocka zabytku w kontekście europejskich drzwi brązowych5.

Zasadniczą jednak rolę odgrywają badania Ursuli Mende. Badaczka ta opublikowała monografię ${ }^{6}$ na temat europejskich drzwi od IX do XII wieku. $\mathrm{W}$ interpretacjach skoncentrowała się przede wszystkim na stylistycznych walorach dzieł. Jednak strona treściowa i ikonograficzna została również potraktowana w należyty sposób. Rozprawa zawiera dokładnie opracowany katalog obiektów. Prezentuje również literaturę przedmiotu.

Publikacje te przynoszą istotne rozpoznanie genezy stylu oraz treści ideowych poszczególnych zabytków. Jednakże zabrakło w nich odczytania

graphique et iconologique de la Porte de Gniezno, „Polish Art Studies” 2 (I980), s. 3I-49; A. Łapiński, Wystawienie zwłok św. Wojciecha $w$ drzwiach gnieźnieńskich, „Biuletyn Historii Sztuki" 40 (1978), s. 95-I03; P. Skubiszewski, L'art. Mosan et la Pologne à l'époque romane: Problématique de recherches, w: Rapports historiques et artistiques entre le Pays mosan et la Pologne, du XIe au début du XIIIe siècle, Liège 198I, s. 27-8I; P. Skubiszewski, La porta della cattedrale di Gniezno, w: Le porte di bronzo dall'antichità al secolo XIII, Roma I990, vol. I, s. 247-270; vol. 2, tab. 187-212.

4 Romańskie Drzwi Płockie II54 - ok. I430-I982, koncepcja, układ treści J. Chojnacki, Płock I983, passim.

5 Por. R. Knapiński, Drzwi Płockie na tle innych romańskich drzwi kościelnych w Europie, w: Romańskie Drzwi Płockie..., dz. cyt., s. I2-29; R. Knapiński, , Credo Apostolorum ' w romańskich Drzwiach Płockich, Płock 1992, passim; R. Knapiński, The Iconography of the Romanesque Ptock Door (Novogrod) as Symbol of the Universal Character Ecclesiastical Art, w: Iconography in Cultural Studies. Paper from the International Conference: European Iconography East and West, ed. by A. Kiss, Szeged I996, s. 53-66; R. Knapiński, L'iconographia del „Collegio dei Apostoli” come illustrazione del Credo nell'arte europea, w: Figurae fidei. Strategie di ricerca nel Medioevo, a cura di T. Rossi, Studi 2003, s. II-40; R. Knapiński, Postfazione. L'iconografia del Credo come manifestazione della fede mediante le imagini sacre, w: R. Mastacchi, Il Credo nell'arte cristiana italiana, Siena 2007, s. I73-I85; R. Knapiński, L'iconografia del Credo (Simbolo degli apostoli) mediante la rappresentazione del Collegio Apostolico nella storia dell'arte europea, w: R. Mastacchi, R. Knapiński, CREDO. La raffigurazione del Simbolo Apostolico nell'arte europea, prefazione di J. T. Spike, Siena 20II, s. II-97; R. Knapiński, Porta fidei-Brama wiary: Romańskie Drzwi Płockie w Nowogrodzie Wielkim, Płock 20I2, passim.

6 U. Mende, Die Bronzetüren des Mittelalters. 800-I200, München I983. 
drzwi z ich zasobem ikonograficznym w kontekście przestrzeni kościelnej i w kontekście liturgii. Niniejsza praca stanowi próbę zmierzenia się z tą problematyką i zaproponowania pewnych rozwiązań. Punktem wyjścia muszą być strukturalne i ikonograficzne analizy wybranych obiektów.

\section{DrzWi z Hildesheim}

Drzwi z kościoła św. Michała w Hildesheim powstały w roku IOI5 z inspiracji i przy osobistym udziale wybitnego duszpasterza, uczonego i mecenasa biskupa Bernwarda ${ }^{7}$. Ich warstwa ikonograficzna ma jasną i wyrazistą strukturę. Każde z dwóch skrzydeł podzielonych jest szeroką bordiurą z napisem fundacyjnym na dwie sekcje o równej wysokości - dolną i górną. Każda z sekcji składa się z czterech kwater o kształcie leżącego prostokąta. W sumie każde ze skrzydeł ma osiem kwater o kształcie leżącego prostokąta.

Znamienne jest rozłożenie akcentów treściowych na każdym ze skrzydeł i w każdej z czterech sekcji. Skrzydło prawe (przyjęto orientację heraldyczną) zawiera sceny ze Starego Testamentu. Narracja obrazowa ma kierunek zstępujący: od góry ku dołowi. Sekcja górna zawiera przedstawienia czterech epizodów Księgi Rodzaju:

- Stworzenie Adama (Rdz 2, 7)

- Stworzenie Ewy (Rdz 2, 2I-22)

- Grzech pierworodny (Rdz 3, 6-7)

- Adam i Ewa przed Bogiem (Rdz 3, 8-19).

Sekcja dolna zawiera epizody będące konsekwencją zdarzeń przedstawionych w sekcji górnej:

- Wygnanie z raju (Rdz 3, 2I-24)

- Praca Adama i macierzyństwo Ewy (Rdz 4, I-2)

- Ofiara Kaina i Abla ( Rdz 3, 3-7)

- Zabójstwo Abla (Rdz 3, 8-Io).

7 Por. S. Kaspersen, Cotton-Genesis, die Toursbibeln und die Bronzetüren - Vorlage und Aktualität, w: Bernwardinische Kunst, Hrsg. M. Gosebruc, F. N. Steigerwald, Göttingen I988, s. 79-I03; B. Gallistl, Die Bronzetüren Bishof Bernward im Dom zu Hildesheim, Freiburg im Breisgau-Basel-Wien I990, passim; B. Gallistl, Bernhard: Die Tür des Bishofs Bernward und ihr ikonographisches Programm, w: Le porte di bronzo..., dz. cyt., vol. I, s. I45-I8I; vol. 2, s. I4I-I5I; U. Mende, Die Bronzetüren ..., dz. cyt., s. 28-33, I35-136. 
Skrzydło lewe (heraldycznie!) zawiera przedstawienia z Nowego Testamentu. Kierunek narracji jest wstępujący: od dołu ku górze.

W pierwszej, dolne sekcji znajdują się sceny dzieciństwa Chrystusa:

- Zwiastowanie (Łk I, 26-38)

- Narodzenie (Łk 2, I-6)

- Pokłon magów (Mt 2, 9-I2)

- Ofiarowanie w świątyni (Ł k 2, 22-40).

Relacje dwóch cyklów narracyjnych - prawego, starotestamentalnego (zstępującego) oraz lewego, nowotestamentalnego (wstępującego) - można określić jako odwrócony paralelizm. Taka sama liczba i położenie sekcji oraz taka sama liczba oraz układ kwater upoważnia do określenia tego związku jako równoległości, jednakże odwrócone kierunki narracji - wstępowanie oraz zstępowanie, a także zasadnicze tematy - upadek ludzkości oraz zbawcze działanie Boga w celu podniesienia człowieka uprawniają do uznania tej relacji jako narracji o dwóch przeciwnych kierunkach.

Znamienny jest również podział treści. W cyklu starotestamentalnym znalazły się epizody mające miejsce w raju oraz poza nim. W cyklu nowotestamentalnym wyróżniają się epizody wcielenia oraz epizody odkupienia.

Treść o ścisłej logice teologicznej, uporządkowanej za pomocą reguł retoryki z zastosowaniem wypowiedzi obrazowych o identycznej spoistości oraz wielkości, świadczy o niepośledniej umysłowości osoby, która podyktowała ten zestaw treści.

\section{DrZWi Z Werony}

Bardzo wczesne, powstałe około roku II38 drzwi zachodniego portalu kościoła św. Zenona w Weronie zdają się wprowadzać pewien paradygmat, który będziemy obserwować w późniejszych drzwiach ${ }^{8}$. Składają się one z 48 kwadratowych kwater, po 24 na każdym ze skrzydeł ułożonych w ośmiu poziomych rejestrach. Przegląd przedstawień zostanie przeprowadzony osob-

8 Por. F. Butturini, Il segno e il tempo nella porta bronzea di San Zeno di Verona, Verona I980, passim; F. Zuliani, La porta bronzea di san Zeno a Verona, w: Le porte di bronzo..., dz. cyt., vol. I, s. 407-4I2; vol. 2, tab. 375-388; U. Mende, Die Bronzetüren..., dz. cyt., s. 57-73, I46-I54. 
no dla każdego ze skrzydeł. Oto przedstawienie skrzydła prawego. Rejestry numerowane są od góry:

- Rejestr I : Zwiastowanie - Narodzenie i zwiastowanie pasterzom Ucieczka do Egiptu

- Rejestr 2: Wypędzenie przekupniów ze świątyni - Chrzest Chrystusa i spotkanie z cudzołożnicą - Dwunastoletni Jezus w świątyni

- Rejestr 3: Wjazd do Jerozolimy - Obmycie nóg - Ostatnia wieczerza

- Rejestr 4: Pojmanie - Niesienie Krzyża - Chrystus przed Piłatem

- Rejestr 5: Biczowanie - Zdjęcie z Krzyża - Niewiasty u grobu

- Rejestr 6: Zstąpienie do Otchłani - Chrystus sędzia - Antaba

- Rejestr 7: Ścięcie św. Jana Chrzciciela - Uczta u Heroda i taniec Salome - Przekazanie głowy Jana Herodiadzie

- Rejestr 8: Drzewo cnót- drzewo wad - Wygnanie z raju - Życie po wygnaniu i zabójstwo Abla

- A oto przedstawienia lewego skrzydła - numeracja rejestrów od góry:

- Rejestr I: Stworzenie Ewy i grzech pierworodny - Pierwsi rodzice przed Bogiem - Wygnanie z raju

- Rejestr 2: Ofiara Kaina i Abla; zabójstwo Abla - Arka Noego - Zawstydzenie Noego

- Rejestr 3: Bóg zaprasza Abrahama do policzenia gwiazd - Abraham

i trzej aniołowie - Hagar wypędzana z domu Abrahama - Ofiarowanie Izaaka

- Rejestr 4: Nadanie przykazań na Synaju: różdżka Aarona - Ostatnia z plag egipskich; Mojżesz i faraon - Wąż miedziany

- Rejestr 5: Prorok Balaam - Drzewo Jessego - Prorok

- Rejestr 6: antaba - św. Zenon łowiący ryby - św. Zenon uzdrawia księżniczkę

- Rejestr 7: Niejasne przedstawienie - Uratowanie opętanego - Galienus i św. Zenon

- Rejestr 8: Ofiarowanie Izaaka - Arka Noego - Walka Michała ze smokiem.

Bogaty zasób treściowy drzwi z bazyliki św. Zenona ujawnia przynajmniej cztery główne wątki. (W niniejszej analizie pominięto mniejsze sceny, umiejsowione na obrzeżach obu skrzydeł). Dominują dwa wątki biblijne (wątek chrystologiczny na skrzydle prawym, wątek starotestamentowy - epizody Księgi Rodzaju i Księgi Wyjścia) oraz wątek św. Jana Chrzciciela i wątek św. Zenona. Trudności w odczytaniu treści sprawiają sceny, które pojawiają się dwukrotnie. Jednakże po wnikliwej obserwacji można stwierdzić, że wątek chrystologiczny i wątek protologiczny (Księga Wyjścia i Księga 
Rodzaju) zyskują przewagę zarówno pod względem liczby epizodów, jak i rozległości narracji. Wynika z tego, że drzwi z Werony, jedne z najwcześniejszych w XII stuleciu, wpisują się w szeroki nurt brązowych ościeży zdobionych cyklami historiozbawczymi. Można więc już teraz postawić pytanie o związek owych obrazowych cykli z celebracją liturgii we wnętrzu kościoła - w przestrzeni sakralnej.

\section{Drzwi Plockie}

Drzwi katedry w Płocku zostały wykonane w Magdeburgu. Ich inspiratorami i twórcami byli dwaj biskupi - Aleksander z Malonne, rządzący stolicą płocką oraz Wichman, arcybiskup Magdeburga. Wskazuje na to napis fundacyjny. Czas powstania określony został na lata II52-II $54^{9}$. W niejasnych okolicznościach drzwi zostały przeniesione do Nowogrodu Wielkiego i zamontowane w soborze św. Zofii.

Każde z dwóch skrzydeł podzielone jest na siedem poziomych rejestrów. Siedem rejestrów mieści po dwie kwadratowe kwatery. Górne rejestry stanowią kwatery o kształcie szerokiego, leżącego prostokąta. Wszystkie pola ograniczone są półwałkową, roślinną bordiurą.

Odczytanie treści sprawia duże trudności, ponieważ układ scen jest zaburzony, zapewne po ponownym złożeniu w Nowogrodzie Wielkim. Należałoby dokonać rekonstrukcji hipotetycznej, która jednakże przekracza ramy niniejszego opracowania. Wydaje się, że dla obecnych potrzeb wystarczy przegląd treści w oparciu o opis dokonany przez Zygmunta Świechowskiego ${ }^{10}$.

9 Por. R. Knapiński, Drzwi Płockie na tle innych romańskich drzwi kościelnych w Europie, w: Romańskie Drzwi Ptockie..., dz. cyt., s. I2-29; K. Askanas, Brąowe drzwi płockie w Nowogrodzie Wielkim, Płock 1971, passim; A. Poppe, Some observations on the bronze doors of the St Sophia in Novogrod, w: Le Pays du Nord et Byzance: Actes du colloque d'Upsal 20-22 avril 1979, Upsala 198I, s. 407-418; U. Mende, Kleinbronzen im Umkreis der Magdeburger Gusswerkstatt, w: Der Magdeburger Dom: Ottonische Gründung und staufischer Neubau, Hrsg. E. Ullmann, Leipzig I989, s. 98-I06, il. 26-57; R. Knapiński, Die romanische Tür von Płock in Novogrod: Neue ikonographish-ikonologische Überlegungen, „Niederdeutsche Beiträge zur Kunstgeschichte” 30 (I99I), s. 29-66; U. Mende, Die bronzetüren..., dz. cyt., s. 74-83, I54-I6I.

ı Z. Świechowski, Sztuka polska: romanizm, Warszawa 2004, s. 303-305. 


\section{Oto treść kwater skrzydła prawego:}

\begin{tabular}{|l|l|}
\hline \multicolumn{2}{|l|}{ Traditio legis } \\
\hline Chrzest Chrystusa/Zwiastowanie/ & Narodzenie \\
\hline Mężczyzna z księgą/Trzej mędrcy & Maria z Dzieciątkiem i anioł/Rachela \\
\hline Ofiarowanie w świątyni & Diakon/kołatka \\
\hline Nawiedzenie Elżbiety/Ucieczka do Egiptu & $\begin{array}{l}\text { Diakon z księgą/Biskup Aleksander Płocki } \\
\text { z dwoma diakonami }\end{array}$ \\
\hline Eliasz na wozie ognistym & Psychomachia (wady i cnoty) \\
\hline $\begin{array}{l}\text { Riquinus odlewnik/Grzech pierworodny/Awram } \\
\text { Nowogrodzki (w miejscu pionowej bordiury) }\end{array}$ & Stworzenie Ewy/Waismuth odlewnik \\
\hline
\end{tabular}

Układ scen w skrzydle lewym przedstawia się następująco:

\begin{tabular}{|l|l|}
\hline \multicolumn{2}{|l|}{ Maiestas Domini } \\
\hline $\begin{array}{l}\text { Mężczyzna - uczestnik wjazdu/Wjazd do } \\
\text { Jerozolimy }\end{array}$ & $\begin{array}{l}\text { Wojownik na bordiurze/Mężczyzna z banderolą } \\
\text { mieszkańcy Jerozolimy z gałązkami }\end{array}$ \\
\hline Mężczyzna z psem/Zdrada Judasza i pojmanie & $\begin{array}{l}\text { Wojownik (na bordiurze)/Mężczyzna z wężem/ } \\
\text { Piotr w więzieniu }\end{array}$ \\
\hline $\begin{array}{l}\text { Kołatka/Król z mieczem/Młodzieniec } \\
\text { z włócznią (na listwie) }\end{array}$ & $\begin{array}{l}\text { Wojownik (na bordiurze)/Herod na tronie/ } \\
\text { Biczowanie }\end{array}$ \\
\hline Ukrzyżowanie/Nikodem? & $\begin{array}{l}\text { Józef z arymatei? (dodany w Nowogrodzie)/ } \\
\text { Niewiasty przy grobie }\end{array}$ \\
\hline Zstąpienie do otchłani/Arcybiskup Wichman & Wniebowstąpienie/Młodzieniec z mieczem \\
\hline Trzej wojownicy/Rzeź niewiniątek & Centaur (dodany w Nowogrodzie) \\
\hline
\end{tabular}

Mimo zaburzonego układu możliwa jest orientacja w głównych wątkach treści. Otóż przedstawienia prawego skrzydła (heraldycznie) są obrazami dzieciństwa i młodości Chrystusa. Wydaje się, że scena chrztu w Jordanie kończy ten cykl. Jego wstępem jest zapewne niewielki zespół scen starotestamentalnych. Kwatery skrzydła lewego zawierają sceny męki, śmierci i zmartwychwstania Chrystusa. Zaczyna je wjazd do Jerozolimy, a kończy 
wniebowstąpienie. Czy możliwe jest odczytanie kierunku narracji obrazowej? Kierunek narracji kwater skrzydła lewego jest zstępujący - od góry do dołu. Natomiast kierunek narracji kwater skrzydła prawego wydaje się być wstępujący, od dołu ku górze, jednakże zatarcie pierwotnego układu i przemieszczenia scen utrudnia jednoznaczne stwierdzenie. Równie dobrze kierunek narracji skrzydła lewego mógł być wstępujący. Jako hipotezę można przyjąć zstępujący kierunek skrzydła prawego i wstępujący skrzydła lewego.

Zasadniczym zrębem treści przedstawień drzwi z Płocka jest historiozbawcza narracja, w której wyodrębniają się dwa bloki, dwa cykle obrazów, wyrażające tajemnicę wcielenia i tajemnicę odkupienia. Jednakże dostrzegamy także ślady innego cyklu, uzupełniającego. Był to cykl Psychomachii, walki cnót z wadami albo cykl walki dobra ze złem.

\section{Drzwi z Katedry w Pizie}

Wykonane przez Bonanusa z Pizy drzwi św. Ranieriego (Porta di san Ranieri), mieszczące się w południowej elewacji transeptu powstały około roku II $80^{\text {II }}$. Każde skrzydło podzielone jest na siedem poziomych rejestrów. Rejestry dolne i górne są wypełnione szerokimi kwaterami o kształcie leżącego prostokąta. W każdym z pozostałych rejestrów umieszczone są po dwie kwatery kwadratowe. Przedstawienia w rejestrach dolnych (rzędy proroków) oraz górnych (Chrystus Pantokrator i tronująca Maria) mają charakter prezentacyjny. Narracja obrazowa zaczyna się w prawej kwaterze rejestru drugiego od dołu na prawym skrzydle i biegnie poziomo od prawego ku lewemu skrzydłu poprzez dwa sąsiadujące rejestry tego samego poziomu.

Układ scen przedstawia się następująco:

- Rejestr I: Prorocy - Prorocy

- Rejestr 2: Zwiastowanie - Nawiedzenie - Narodzenie i Zwiastowanie pasterzom - Pokłon Magów

II Por. W. Melczer, La porta di Bonanno nel Duomo di Pisa: teologia e immagine, Ospedaletto I988, passim; W. Melczer, Le porte bronzee di Bonanno Pisano, w: Le porte di bronzo..., dz. cyt., vol. I, s. 373-387; vol. 2, tab. 335-354; I. Baldelli, Le iscrizioni latine e volgari nelle porte di Bonanno Pisano, w: Le porte di bronzo..., dz. cyt., vol. I, s. 389-397; vol. 2, tab. 355359; S. Heydasch-Lehman, Der ,, Taufbrunnen” in San Frediano in Luca und die Entwicklung 
- Rejestr 3: Ofiarowanie w świątyni - Ucieczka do Egiptu - Rzeź niewiniątek - Ucieczka do Egiptu

- Rejestr 4: Kuszenie Chrystusa - Przemienienie na górze - Wskrzeszenie

Łazarza - Wjazd do Jerozolimy

- Rejestr 5: Obmycie nóg - Ostatnia wieczerza - Pojmanie - Ukrzyżowanie

- Rejestr 6: Zstąpienie do otchłani - Niewiasty u grobu - Wniebowstąpienie - Zaśnięcie Marii

- Rejestr 7: Chrystus Pantokrator - Maria na tronie.

Zadziwia w tym układzie obrazów logika i konsekwencja. W całym układzie istnieje wstęp (prorocy), korpus narracyjny w pięciu rejestrach oraz konkluzja - dwa przedstawienia adoracyjne. W narracji historiozbawczej istnieje ścisła równowaga między scenami dzieciństwa (rejestry 2 i 3) i aktywności publicznej (rejestr 4) oraz śmierci i zmartwychwstania.

Wyraźnie uwypuklona jest rzeczywistość - tajemnice wcielenia i odkupienia. Jasność i wyrazistość układu, wyraźna przewaga scen narracyjnych nad prezentacyjnymi oraz koncentracja na tajemnicach chrześcijaństwa są istotnymi wyznacznikami przedstawień tych drzwi.

\section{Drzwi z Monreale}

Bonanus z Pizy jest również autorem drzwi zachodniego portalu katedry w Monreale. Powstały one w roku II $85^{\text {I2 }}$. Zamykają otwór drzwiowy zakończony od góry łukiem ostrym. Kształt drzwi, dostosowany do otworu drzwiowego, odznacza się wyraźnymi i logicznymi podziałami. Oba skrzydła drzwi są podzielone na I2 poziomych rejestrów. Tylko rejestry górne i dolne mają kształt leżących prostokątów. Każdy z pozostałych rejestrów mieści dwie kwadratowe

der toskanischen Plastik in der 2. Hälfte des I2. Jahrhunderts, Frankfurt am Main-Bern-New York-Paris I99I, s. I38-I49; U. Mende, Die Bronzetüren ..., dz. cyt., s. I02-IIO, I69-I74.

I2 Por. W. Melczer, La porta di Bonanno a Monreale: teologia e poesia, Palermo I987, passim; J. White, The bronze doors of Bonanus and the development of dramatic narrative, „Art History" II (1988), s. I58-I94; W. Melczer, Le porte bronzee di Bonanno Pisano, w: Le porte di bronzo..., dz. cyt., vol. I, s. 373-387; vol. 2, tab. 335-354; I. Baldelli, Le iscrizioni latine e volgari nelle porte di Bonano Pisano, w: Le porte di bronzo..., dz. cyt., vol. I, s. 389-397; vol. 2, tab. 355-359; U. Mende, Die Bronzetüren..., dz. cyt., s. I02-IIO, I69-I74. 
kwatery. Rejestry dolne z przedstawieniami gryfa i lwa symbolizującymi zło i zagrożenie oraz rejestry górne - z Chrystusem Pantokratorem na lewym i tronującą Marią na lewym skrzydle mają charakter prezentacyjny. Pozostałe kwatery mieszczą narracyjny cykl historiozbawczy. Narracja biegnie od dołu, od drugiego rejestru od prawej kwatery prawego skrzydła do lewej kwatery lewego skrzydła. Oto układ treści.

- Rejestr I: Gryf i lew - gryf i lew

- Rejestr 2: Stworzenie Adama - Stworzenie Ewy - Adam i Ewa w raju Grzech pierworodny

- Rejestr 3: Wygnanie z raju - Praca Adama i Ewy - Narodziny Kaina i Abla - Kain i Abel

- Rejestr 4: Zabojstwo Abla - Arka Noego - Sceny z Noem - Abraham i trzej goście

- Rejestr 5: Ofiara Izaaka - Trzej patriarchowie - Mojżesz i Aaron - Malachiasz i Balaam

- Rejestr 6: Ozeasz i Izajasz - Micheasz i Joel - Daniel i Amos - Ezechiel i Zachariasz

- Rejestr 7: Zwiastowanie - Nawiedzenie - Narodzenie i Zwiastowanie pasterzom - Trzej Królowie

- Rejestr 8: Rzeź niewiniątek - Ucieczka do Egiptu - Ofiarowanie w świątyni - Chrzest Chrystusa

- Rejestr 9: Kuszenie Chrystusa - Wskrzeszenie Łazarza - Wjazd do Jerozolimy - Przemienienie na górze

- Rejestr Io: Ostatnia wieczerza - Pojmanie - Ukrzyżowanie - Zstąpienie do otchłani

- Rejestr II: Niewiasty u grobu - Noli me tangere - Uczniowie z Emaus Wniebowstąpienie

- Rejestr I2: Tronująca Maria - Chrystus Pantokrator

W treści przedstawień obserwujemy nową jakość. Jest nią rozbudowany blok starotestamentowy. Pięć rejestrów (2-6) wypełniają przedstawienia ze Starego Testamentu. Są to zarówno wydarzenia, jak i osoby - proroków i patriarchów. Blok starotestamentowy równoważy blok scen zbawczych z Nowego Testamentu, który również zajmuje pięć rejestrów (7-II). W tym zespole nie ma wyraźnego podziału na epizody tajemnicy wcielenia i tajemnicy odkupienia, jednakże możliwe jest dokładne rozróżnienienie obu tajemnic. 


\section{DRZWI Z CYKLAMI NARRACYJNYMI: ZAPOWIEDŹ LITURGII CZY ODPOWIEDŹ NA LITURGIĘ?}

Na początku tej części, która będzie poświęcona interpretacji, należy przedstawić dwa zastrzeżenia. Po pierwsze, nie należy traktować zespołów obrazów na monumentalnych drzwiach wiodących do kościoła jako zastępczej katechezy obrazowej, przeznaczonej dla prostych wiernych, pozbawionych umiejętności czytania i pisania. Owe zespoły są złożonymi cyklami narracyjnymi, których koncepcje tworzyli ludzie o wysokimi ówczesnym wykształceniu i głębokiej kulturze religijnej. Układ scen, dynamika narracji, dobór treści i rozłożenie akcentów wynikają z wiedzy i wrażliwości teologicznej. Ogląd cyklów obrazowych drzwi przeznaczony był w zasadzie dla duchownych oraz innych osób wykształconych. Owszem, mogli mieć dostęp do nich i prości wierni, jednak ich obecność domagała się kogoś, kto mógłby im przedstawienia wyjaśnić. Obrazy nie zastępowały pisma. Wręcz przeciwnie, w wielu przypadkach są one opatrywane napisami. Zrozumienie ich treści wymagało odczytania napisów i zespolenia treści słownych i obrazowych.

Po drugie, drzwi nie stanowiły samodzielnego medium przekazu treści i wyodrębnionego, samodzielnego dzieła sztuki. Były one zapewne w przeważającej liczbie częścią programu architektonicznego i ewentualnie fasady kościoła lub innej elewacji. Obecnie w wielu przypadkach pierwotna fasada nie istnieje lub też drzwi mogły zostać wyrwane ze swego pierwotnego środowiska $i$ być wmontowane w innym kościele lub stać się przedmiotem muzealnym. Straciły więc więź ze swym pierwotnym kontekstem.

Tam, gdzie to jest możliwe, należy intepretować drzwi w obrębie fasady, jednakże w większości przypadków będą one traktowane jako relikt większego dzieła, choćby nawet był w doskonałym stanie. Nie należy oczywiście rezygnować z badania reliktu i wyciągania pewnych wniosków. Stajemy zatem w obliczu pytania: jaki był pierwotny związek cyklów obrazowych drzwi brązowych z liturgią sprawowaną w kościele, do którego owe drzwi otwierały dostęp?

Analiza powyższych pięciu zabytków pozwala na pewną konstatację, która identyfikuje rdzeń treści wszystkich narracji obrazowych. Tym rdzeniem jest chrystologiczny cykl nowotestamentowy, w mniejszym lub większym stopniu podzielony na dwie zasadnicze części - część wizualizującą tajemnicę wcielenia i cześć wizualizującą tajemnicę odkupienia. Głównym protagonistą tej rdzeniowej narracji jest Jezus Chrystus.

W tym miejscu zasadne jest odnieść się do cennego odczytania drzwi kościoła jako takich, nawet bez uwzględniania cyklów obrazowych, jakiego 
dokonał Lech Kalinowski. Odczytał on, zarówno otwór wejściowy, jak i drzwi, jako symbol Chrystusa. Chodzi o Chrystusa, bądź to zamykającego wstęp złu (ostium od obsistere), bądź otwierającego drogę do zbawienia (ostium od ostendere). Przywołał przy tym słowa Jezusa (J I0, 9; J I4, 6) ${ }^{13}$. Umieszczenie na drzwiach cyklów scen chrystologicznych wynika z tego, że drzwi prowadzące do kościoła postrzegane były symbolicznie. Rozpoznawano w nich bowiem Chrystusa, który samego siebie określał jako bramę. Jednak to rozpoznanie nie daje jasnej odpowiedzi na pytanie o związek między wprowadzającymi do kościoła drzwiami a rozgrywającą się w nim liturgią. Co mogło ukonstytuować ów związek? Była nim alegoryczna interpretacja liturgii eucharystycznej.

Początków tej interpretacji należy szukać w renesansie karolińskim i podejmowanych wtedy reformach liturgicznych. Alegoryczne odczytywanie liturgii zapoczątkował Alkuin. Jednak mistrzem alegoryki liturgicznej okazał się Amalariusz z Metzu. W swym dziele De ecclesiasticis officiis libri quatuor szczegółowo przedstawił przebieg liturgii mszalnej'it. Poszukując zrozumienia gestów, słów, ruchu, sytuacji i osób, uciekł się do alegorii, intepretując elementy liturgii, nawet bardzo drobne i z pozoru nic nieznaczące jako epizody z życia Chrystusa. Można podać kilka przykładów. Wejście biskupa do prezbiterium na początku celebracji mszy świętej, dokonujące się aż do momentu zajęcia miejsca na tronie autor rozumie jako sprawowanie przez Chrystusa-człowieka, wcielonego Syna Bożego, Jego urzędu na ziemi, dopóki nie w odejdzie do Ojca (De ecclesiasticis officiis, liber III, caput V). Biskup-celebrans przechodzący od ołtarza na prawą stronę oznacza Chrystusa, który przechodzi z życia ziemskiego do niebieskiego (De ecclesiasticis officiis, liber III, caput VII). Drewniany stopień, na który wchodzi osoba głosząca słowo Boże, oznacza mękę Chrystusa. Ten, kto wstępuje na ten stopień, decyduje się naśladować mękę Pańską (De ecclesiasticis officiis, liber III, caput $\mathrm{XV}$ ). Słowa ustanowienia i przeistoczenia rozumiane są jako ofiara, którą Chrystus składa za grzeszników, aby tą ofiarą pojednać ich z Bogiem i uczynić zdolnymi do składania ofiar, bowiem oni sami żadnej ofiary Bogu złożyć nie mogą. Chrystus staje się zatem Hostią, złożoną za sprawiedliwych i niesprawiedliwych. Krzyż uczyniony nad chlebem i winem, które mają być

\footnotetext{
I3 Por. L. Kalinowski, Treści ideowe i estetyczne Drzwi Gnieźnieńskich, dz. cyt., s. 324.

${ }^{14}$ Symphosius Amalarius, De ecclesiasticis officiis libri quatuor, w: Theodulfi Aurelianensis episcopi, Sancti Eigilis abbatis Fuldensis, Dungali Reclusi, Ermoldi Nigelli, Symphosii Amalarii presbyteri Metensis Opera omnia [...], accurante J.-P. Migne, Paris I864, k. 935-I242 (Patrologiae Cursus Completus. Series Latina, I05).
} 
ofiarowane, oznacza, że rzeczywiście Chrystus został ukrzyżowany (De ecclesiasticis officiis, liber III, caput XXIV).

Wydaje się więc, że uznanie alegorycznej interpretacji liturgii mszalnej jako podłoża obrazowania i komponowania cyklów chrystologicznych w drzwiach brązowych jest właściwym rozwiązaniem. Należy wziąć pod uwagę, że interpretacja ta była rozpowszechniona wśród wykształconych i uformowanych duchownych posługujących w kościołach, które zaopatrywano w drzwi brązowe. Z grupy tych właśnie duchownych mógł się poza tym wywodzić teolog, który dyktował program ikonograficzny odrzwi, nakazywany do realizacji zespołom rzemieślników.

Konieczne jest jednak z uwypuklenie istnienia dwóch sposobów chrystologicznego rozumienia liturgii. Pierwszym sposobem jest odniesienie konkretnych przedmiotów, gestów, czynności i sytuacji do konkretnych, udokumentowanych w ewangeliach epizodów z życia Chrystusa. W tym przypadku przebieg liturgii mszalnej koresponduje z narracją ewangeliczną o życiu Chrystusa. Drugim sposobem jest głębsze rozumienie całości życia i dzieła Chrystusa. Odrywa się ono od narracji ewangelicznej. Dotyczy ona bowiem nie epizodów historycznych, lecz dwóch tajemnic Jezusa Chrystusa - wcielenia i odkupienia. To drugie rozumienie dominuje w cyklach narracyjnych brązowych drzwi.

Należy jednak zwrócić uwagę na pewien znamienny fakt. Otóż przedstawione obrazy mają zbliżającego się do drzwi człowieka wprowadzać w liturgię, a ściślej w jej tajemnicę. Jednakże te zespoły obrazów są już rezultatem pewnego rozumienia liturgii i odczytania jej głębokiego sensu, dokonanego przez osobę wykształconą teologicznie... Tak więc osoba, która wchodzi w przestrzeń liturgii, zanim rozpocznie uczestnictwo w niej, ma już przed oczyma jej sens i orędzie zwizualizowane poprzez obrazy na kwaterach. Konkludując, można stwierdzić, że cykle chrystologiczne na analizowanych drzwiach są zarówno zapowiedzią liturgii, jak i odpowiedzią na nią.

\section{Przypadki szczególne. Co zapowiadają I Jakie orędzie NIOSĄ DRZWI O CYKLACH HAGIOGRAFICZNYCH I SYMBOLICZNYCH?}

Najbardziej chyba znane i przywoływane w polskiej kulturze drzwi z katedry gnieźnieńskiej stanowią problem badawczy i nie dają łatwej odpowiedzi 
na pytanie o rozumienie znajdujących się na nich przedstawień i funkcji tych przedstawień ${ }^{15}$. Obszerna rozprawa ikonologiczna Kalinowskiego wyjaśnia genezę typów ikonograficznych przedstawień, proweniencje stylu i funkcje, jednakże nie mówi o związkach z liturgią ${ }^{16}$. Wielu zresztą badaczy podejmowało próby odczytania głębokich treści zespołu obrazów drzwi ${ }^{17}$. Aby podjąć próbę tego wyjaśnienia, należy przyjrzeć się treści. Każde ze skrzydeł mieści zespół ośmiu kwater o kształcie leżącego prostokąta. Blok kwater na skrzydle otoczony jest bordiurą zbudowaną na sinusoidalnej wici winorośli z wplecionymi weń symbolicznymi scenami.

Na prawym skrzydle (heraldycznie), o przebiegu narracji od dołu ku górze, znajdują się następujące sceny:

- Narodzenie Wojciecha

- Ofiarowanie Wojciecha

- Oddanie Wojciecha do szkoły katedralnej w Magdeburgu

- Modlitwa Wojciecha u grobu męczennika

- Ustanowienie św. Wojciecha biskupem

- Egzorcyzmy św. Wojciecha

- Ukazanie się Chrystusa Wojciechowi we śnie

- Wojciech napomina księcia Bolesława I

- Cud z dzbankiem na Awentynie

Lewe skrzydło (heraldycznie), o przebiegu narracji od góry ku dołowi, zawiera następujące sceny:

- Przybycie Wojciecha do Prus

- Chrzest Prusów

- Kazanie Wojciecha do Prusów

- Msza Wojciecha

- Męczeństwo Wojciecha

- Wystawienie ciała Wojciecha

- Wykupienie ciała męczennika

${ }_{15}$ Por. Drzwi Gnieźnieńskie, t. I-3, red. M. Walicki, Wrocław 1956-I959 [zawartość - patrz przypis I];

I6 Por. L. Kalinowski, Treści ideowe i estetyczne Drzwi Gnieźnieńskich, dz. cyt., passim.

${ }_{17}$ Por. S. Mossakowski, La Porte de bronze de Gniezno et la „Chronique polonaise” de maître Vincent, dz. cyt., s. II-29; J. S. Pasierb, Le programme iconographique et iconologique de la Porte de Gniezno, dz. cyt., s. 3I-49; A. Łapiński, Wystawienie zwłok św. Wojciecha $w$ drzwiach gnieźnieńskich, dz. cyt., s. 95-I03; P. Skubiszewski, L'art. Mosan et la Pologne à l'époque romane..., dz. cyt., s. 27-8I; P. Skubiszewski, La porta della cattedrale di Gniezno, dz. cyt., vol. I, s. 247-270; vol. 2, tab. I87-2I2. 
- Translacja ciała Wojciecha

- Złożenie ciała do grobu.

Cykl życia świętego zdaje się nie mieć żadnych związków z liturgią. Owszem, nawet pobieżna analiza cyklu narracyjnego pozwala stwierdzić, że obrazy kształtowane są na wzór obrazów z życia Chrystusa, a cały cykl jest kształtowany na podobieństwo dwoistości życia Chrystusa (dzieciństwo i aktywność publiczna oraz męka i śmierć). Co więcej, obecność drzwi z obrazami hagiograficznymi w katedrze gnieźnieńskiej, stanowiąca martyrium biskupa i męczennika, jest jak najbardziej uzasadniona. Jednakże pytanie o związek z rozgrywającą się we wnętrzu kościoła liturgią, nawet pod ołtarzem, gdzie złożono relikwie św. Wojciecha, nadal pozostaje bez odpowiedzi.

Jeszcze większy problem stanowią drzwi, które są dziełami Barisanusa z Trani. Są to drzwi z zachodniego portalu katedry w Ravello z roku II79 oraz drzwi z zachodniego portalu katedry w Trani z lat II80-II90 ${ }^{18}$.

Zadziwiające jest, że oba skrzydła drzwi z Ravello mają identyczny układ i prawie identyczny zestaw przedstawień, zaburzony jedynie w górnej części. Każde ze skrzydeł podzielone jest na dziewięć poziomych rejestrów. W nich umieszczone są trzy kwatery o kształcie stojącego prostokąta oddzielone ornamentalnymi listwami. A oto treść kwater - numeracja rejestrów biegnie od dołu ku górze:

- Rejestr I: skrzydło prawe: Drzewo życia w każdej z kwater; skrzydło lewe: Drzewo życia w każdej z kwater

- Rejestr 2: skrzydło prawe: Drzewo życia w każdej z kwater; skrzydło lewe: Drzewo życia w każdej z kwater

- Rejestr 3: skrzydło prawe: Łucznik - napis fundacyjny - Dwaj walczący wojownicy; skrzydło lewe: Łucznik - napis fundacyjny - Dwaj walczący wojownicy

- Rejestr 4: skrzydło prawe: św. Eustachy - Eliasz - św. Jerzy; skrzydło lewe: św. Jerzy - św. Paweł - św. Eustachy

- Rejestr 5: skrzydło prawe: św. Jan Chrzciciel - kołatka - Maria z Dzieciątkiem; skrzydło lewe: Maria z Dzieciątkiem - kołatka - Eliasz

${ }_{18}$ Por. D. A. Walsh, The iconography of the bronze doors of Barisanus of Trani, „Gesta” 2I (I982) no. 2, S. 9I-I06; W. Melczer, La porta di bronzo di Barisano daTrani a Ravello: Iconografia e stile, Cava dei Tirreni I984, passim; B. Ronchi, La cattedrale di Trani, Fasano I986, s. 2I7-23I; D. A. Walsh, The bronze doors of Barisanus of Trani, w: Le porte di bronzo..., dz. cyt., vol. I, s. 399-406; vol. 2, tab. 30I-373; H. Roberts, T. M. Izbicki, The fighting figures of Barisano of Trani, „Source” II (I99I), s. 7-I3; U. Mende, Die Bronzetüren..., dz. cyt., s. 94-IOI, I64-I69. 
- Rejestr 6: skrzydło prawe: św. Tomasz Apostoł - św. Bartłomiej św. Mikołaj z fundatorem; skrzydło lewe: Mikołaj z fundatorem - św. Jakub Mniejszy - św. Andrzej

- Rejestr 7: skrzydło prawe: św. Tadeusz Apostoł - Zstąpienie do otchłani - św. Piotr; skrzydło lewe: św. Filip - Zstąpienie do otchłani - św. Mateusz

- Rejestr 8: skrzydło prawe: św. Tomasz Apostoł - Zdjęcie z Krzyża św. Jan Ewangelista: skrzydło lewe : św. Jakub Starszy - Maiestas Domini - Rejestr 9: skrzydło prawe: anioł - Maiestas Domini - anioł; skrzydło lewe: anioł - Maiestas Domini - anioł.

W przypadku tego zespołu przedstawień zdolność ujawniania treści liturgii można by przypisać jedynie trzem przedstawieniom w trzech ostatnich, górnych rejestrach - Zstąpienie do otchłani, Zdjęcie z krzyża i Maiestas Domini. W porównaniu jednak z całym zasobem obrazów, gdzie obecne są symbole - drzewo życia i zbrojni, a dominują zestawy świętych, te trzy obrazy, choć ich treść jest doniosła, wydają się jedynie aluzją i niewielką wzmianką. Właściwie rodzi się pytanie: co jest istotną treścią całej struktury obrazowej drzwi z Ravello? Jakie przesłanie niosą te drzwi o powtarzalnych obrazach $i$ analogicznej strukturze?

- Nie mniej pytań przynoszą drzwi z Trani. Zasada analogiczności struktury skrzydeł jest tam zachowana, a dziewięć rejestrów po dwie prostokątne kwatery w każdym zawiera następujący zespół przedstawień - numeracja od dołu ku górze:

- Rejestr I: skrzydło prawe: Dwaj walczący wojownicy - Drzewo życia; skrzydło lewe: Łucznik - Dwaj walczący wojownicy

- Rejestr 2: skrzydło prawe: Drzewo życia - Łucznik; skrzydło lewe: Łucznik - Drzewo życia

- Rejestr 3: skrzydło prawe: św. Jerzy - kołatka; skrzydło lewe: kołatka św. Eustachy

- Rejestr 4: skrzydło prawe: św. Filip - św. Bartłomiej; skrzydło lewe: Mikołaj pielgrzym - Zdjęcie z krzyża

- Rejestr 5: skrzydło prawe: św. Jan Chrzciciel - św. Paweł; skrzydło lewe: św. Juda Tadeusz - św. Andrzej

- Rejestr 6: skrzydło prawe: św. Jan Ewangelista - św. Tomasz; skrzydło lewe: św. Szymon - Zstąpienie do otchłani

- Rejestr 7: skrzydło prawe: św. Jakub Młodszy - Maria z Dzieciątkiem; skrzydło lewe: św. Piotr - Eliasz

- Rejestr 8: skrzydło prawe: Anioł - Maiestas Domini; skrzydło lewe: Anioł - Maiestas Domini. 
W przypadku tych drzwi owa wzmianka chrystologiczna, która mogłaby być uznana za odniesienie do liturgii, jest jeszcze bardziej zredukowana. Zastanawia bardzo znacząca obecność kolegium apostolskiego zarówno na odrzwiach z Ravello, jak i z Trani. Byłaby ona czymś oczywistym jako odzwierciedlenie apostolskości, jako wizualizacja filarów Kościoła, jakimi są apostołowie.

Jednakże próba odnalezienia analogii treści tych obrazów z treściami liturgii nasuwa niemałe trudności. W sposobie usytuowania przedstawień w kwaterach obu drzwi dostrzegamy pewną dynamikę. Dynamiką tą jest wyraźny kierunek wstępowania od dołu ku górze. Następuje przejście od sytuacji walki i opresji w dolnych kwaterach, poprzez postacie świętych myśliwych i wojowników (Jerzy, Eustachy), następnie apostołów aż do przedstawień na szczycie, jakim jest Maiestas Domini. Należałoby odnaleźć podobną linię w strukturze liturgii eucharystycznej. Jednak należy to pozostawić dalszym badaniom.

Jednak najbardziej tajemnicze i sprawiające największe trudności badawcze są drzwi z południowego transeptu katedry w Augsburgu, powstałe na początku XI wieku' ${ }^{19}$. Drzwi te były pierwotnie planowane jako dwuskrzydłowe, gdzie każde skrzydło podzielone zostało na siedem rejestrów po dwie prostokątne kwatery. Przy późniejszej przeróbce wstawiono wąskie, pionowe płyty między kwatery skrzydła prawego (heraldycznie). Ponadto położenie kwater zostało zaburzone. Mimo że Urszula Mende zaproponowała pewną rekonstrukcję, trudno rozeznać, jaki był pierwotny układ przedstawień i pierwotna dynamika ewentualnej narracji ${ }^{20}$. Ewentualnej, ponieważ mamy do czynienia z powściągliwymi przedstawieniami jednej osoby w różnych sytuacjach. Ponieważ program obrazowy jest w obecnym stanie trudny do zrozumienia, użyteczne wydaje się przytoczenie rekonstrukcji:

19 Por. T. Droste, Die Bronzetür des Augsburger Domes, „Jahrbuch des Vereins für Augsburger Bistumsgeschichte" I4 (I980), s. 7-76; I5 (I98I), s. I69-20I3; A. Burmester, J. Koller, Die romanischen Domtüren am Dom zu Augsburg, „Maltechnik/Restauro” 9I (1985) 4, s. 9-23; R. Jacob, Die Vorstellungswelt der Bronzetüren des Augsburger Domes, „Zeitschrift des Historischen Vereins für Schwaben" 79 (1985), s. III-I6I; C. D. Sheppard, The bronze doors of Augsburg Cathedral, w: Hortus imaginum: Studies in western art, Lawrence 1974, s. 2I-27, i1. I5-I6; C. D. Sheppard, The bronze doors of Augsburg Cathedral, w: Le porte di bronzo..., dz. cyt., vol. I, s. I83-I88; vol. 2, tab. I53-I57; U. Mende, Die Bronzetüren..., dz. cyt., s. $34-40137-$ I39.

20 Por. U. Mende, Die Bronzetüren..., dz. cyt., s. 39. 


\begin{tabular}{|l|l|l|l|}
\hline Drzewo życia & Drzewo życia & $\begin{array}{l}\text { Drzewo życia i postać } \\
\text { ludzka }\end{array}$ & $\begin{array}{l}\text { Lew pożerający } \\
\text { człowieka }\end{array}$ \\
\hline $\begin{array}{l}\text { Samson walczący oślą } \\
\text { szczęką }\end{array}$ & $\begin{array}{l}\text { Samson rozdzierający } \\
\text { lwa }\end{array}$ & $\begin{array}{l}\text { Samson rozdzierający } \\
\text { lwa }\end{array}$ & $\begin{array}{l}\text { Samson walczący oślą } \\
\text { szczęką }\end{array}$ \\
\hline Postać męska & Uzbrojony król & Uzbrojony król & Postać męska \\
\hline Lew & Centaur & Centaur & Lew \\
\hline Mojżesz i wąż & Kołatka & Kołatka & Mojżesz i wąż \\
\hline $\begin{array}{l}\text { Mężczyzna jedzący } \\
\text { winogrona }\end{array}$ & $\begin{array}{l}\text { Mężczyzna unoszący } \\
\text { flakon }\end{array}$ & $\begin{array}{l}\text { Mężczyzna unoszący } \\
\text { flakon }\end{array}$ & $\begin{array}{l}\text { Mężczyzna jedzący } \\
\text { winogrona }\end{array}$ \\
\hline Mężczyzna z tarczą & $\begin{array}{l}\text { Kobieta karmiąca } \\
\text { ptaki }\end{array}$ & $\begin{array}{l}\text { Kobieta karmiąca } \\
\text { ptaki }\end{array}$ & Mężczyzna z tarczą \\
\hline
\end{tabular}

Natomiast pionowo rząd smukłych kwater, wstawionych później między dwa rzędy prawego skrzydła, zawiera następujące przedstawienia - ujęte od dołu ku górze:

- Udzielenie duszy Adamowi

- Stworzenie Ewy

- Mężczyzna

- Aaron i węże

- Mojżesz z trędowatą ręką

- Aaron i kwitnąca różdżka

- Mojżesz i wąż.

Mende, uwzględniając wszystkie przedstawienia, wyróżnia trzy grupy tematyczne. Są nimi: I. stworzenie człowieka, 2. prefiguracje Chrystusa, 3. symboliczne zwierzęta. Badaczka stanęła jednak przed trudnością rozpoznania wielu symbolicznych przedstawień. Stwierdziła, że każde z przedstawień w kwaterach może mieć swoje własne znaczenie symboliczne ${ }^{21}$. Ostatecznie wyróżniła ona antynomiczne tematy dobra i zła oraz zbawienia i potępienia ${ }^{22}$. Tak więc odpowiedź na pytanie o związek tego zespołu obrazów z liturgią jest uwarunkowana stworzeniem możliwie bliskiej oryginałowi hipotetycznej rekonstrukcji układu, rozwiązaniem zagadek poszczególnych przedstawień oraz odczytaniem orędzia całości kwater w obrębie drzwi.

${ }_{21}$ Por. U. Mende, Die Bronzetüren..., dz. cyt., s. 40.

22 Por. U. Mende, Die Bronzetüren..., dz. cyt., s. I37. 


\section{WNIOSKI}

Brązowe drzwi z cyklami przedstawień figuralnych reprezentują bogactwo tematów ikonograficznych kwater i wielość programów zespołów obrazowych. Podstawową funkcją drzwi jest wprowadzenie do przestrzeni kościoła, która z natury swej jest przestrzenią liturgiczną. Jednakże okazuje się, że jedynie niektóre cykle obrazów - chrystologiczne - można powiązać ze sprawowaną we wnętrzu kościoła liturgią. Cykle te bowiem wyrażają tajemnicę Chrystusa w jej dwóch aspektach - wcielenia i odkupienia. Nie przyniosła rezultatów próba powiązania z liturgią drzwi zdobionych obrazowymi cyklami symbolicznymi i hagiograficznymi. Można jednak żywić uzasadnioną nadzieję, że dalsze badania pozwolą w pełni odczytać ich głębokie znaczenie, zidentyfikować ich funkcje oraz zrozumieć związek z wnętrzem kościelnym.

\section{Bibliografia}

Askanas K., Brazowe drzwi płockie w Nowogrodzie Wielkim, Płock I97I.

Baldelli I., Le iscrizioni latine e volgari nelle porte di Bonano Pisano, w: Le porte di bronzo dall'antichità al secolo XIII, Roma I990, vol. I, s. 389-397; vol. 2, tab. 355-359.

Burmester A., Koller J., Die romanischen Domtüren am Dom zu Augsburg, „Maltechnik/Restauro" 9I (I985) 4, s. 9-23.

Butturini F., Il segno e il tempo nella porta bronzea di San Zeno di Verona, Verona 1980.

Droste T., Die Bronzetür des Augsburger Domes, „Jahrbuch des Vereins für Augsburger Bistumsgeschichte" I4 (I980), s. 7-76; I5 (I98I), s. I69-20I3.

Drzwi Gnieźnieńskie, t. I-3, red. M. Walicki, Wrocław I956-I959.

Gallistl A., Bernhard: Die Tür des Bishofs Bernward und ihr ikonographisches Programm, w: Le porte di bronzo dall'antichità al secolo XIII, Roma 1990, vol. I, s. I45-I8I; vol. 2, s. I4I-I5I.

Gallistl A., Die Bronzetüren Bishof Bernward im Dom zu Hildesheim, Freiburg im Breisgau-Basel-Wien I990.

Gieysztor A., Drzwi Gnieźnieńskie jako wyraz polskiej świadomości narodowościowej XII wieku, w: Drzwi Gnieźnieńskie, t. I, red. M. Walicki, Wrocław I956, S. I-I9. 
Heydasch-Lehman S., Der „Taufbrunnen” in San Frediano in Luca und die Entwicklung der toskanischen Plastik in der 2. Hälfte des I2. Jahrhunderts, Frankfurt am Main-Bern-New York Paris I99I.

Jacob R., Die Vorstellungswelt der Bronzetüren des Augsburger Domes, „Zeitschrift des Historischen Vereins für Schwaben“ 79 (I985), S. III-I6I.

Kalinowski L., Treści ideowe i estetyczne Drzwi Gnieźnieńskich, w: Drzwi Gnieźnieńskie, t. I, red. M. Walicki, Wrocław I956, s. 7-I60.

Kalinowski L., Treści ideowe i estetyczne Drzwi Gnieźnieńskich, w: L. Kalinowski, Speculum artis: treści dzieła sztuki średniowiecza i renesansu, Warszawa 1989, s. 227-378.

Karwasińska J., Drzwi Gnieźnieńskie a rozwój legendy o biskupie Wojciechu, w: Drzwi Gnieźnieńskie, t. I, red. M. Walicki, Wrocław I956, s. 20-4I.

Kaspersen S., Cotton-Genesis, die Toursbibeln und die Bronzetüren - Vorlage und Aktualität, w: Bernwardinische Kunst, Göttingen I988, s. 79-I03.

Kępiński Z., Symbolika drzwi gnieźnieńskich, w: Drzwi Gnieźnieńskie, t. I, red. M. Walicki, Wrocław I956, s. I6I-38I.

Knapiński R., ,, Credo Apostolorum” w romańskich Drzwiach Płockich, Płock I992.

Knapiński R., Drzwi Płockie na tle innych romańskich drzwi kościelnych w Europie, w: Romańskie Drzwi Płockie II54 - ok. I430-I982, Płock I983, S. I2-29.

Knapiński R., L'iconographia del „Collegio dei Apostoli” come illustrazione del Credo nell'arte europea, w: Figurae fidei. Strategie di ricerca nel Medioevo, a cura di T. Rossi, Studi 2003, s. II-40.

Knapiński R., L'iconografia del Credo (Simbolo degli apostoli) mediante la rappresentazione del Collegio Apostolico nella storia dell'arte europea, w: R. Mastacchi, R. Knapiński, CREDO. La raffigurazione del Simbolo Apostolico nell'arte europea, prefazione di John T. Spike, Siena 20II, S. II-97.

Knapiński R., The Iconography of the Romanesque Ptock Door (Novogrod) as Symbol of the Universal Character Ecclesiastical Art, w: Iconography in Cultural Studies. Paper from the International Conference: European Iconography East and West, ed. by A. Kiss, Szeged 1996, s. 53-66.

Knapiński R., Porta fidei - Brama wiary: Romańskie Drzwi Plockie w Nowogrodzie Wielkim, Płock 2012.

Knapiński R., Postfazione. L'iconografia del Credo come manifestazione della fede mediante le imagini sacre, w: R. Mastacchi, Il Credo nell'arte cristiana italiana, Siena 2007, s. I73-I85. 
Knapiński R., Die romanische Tür von Płock in Novogrod: Neue ikonographish-ikonologische Überlegungen, „Niederdeutsche Beiträge zur Kunstgeschichte" 30 (I99I), s. 29-66.

Łapiński A., Wystawienie zwłok św. Wojciecha $w$ drzwiach gnieźnieńskich, „Biuletyn Historii Sztuki” 40 (I978), s. 95-I03.

Melczer W., La porta di Bonano a Monreale: teologia e poesia, Palermo I987.

Melczer W., La porta di Bonano nel Duomo di Pisa: teologia e immagine, Ospedaletto I988.

Melczer W., La porta di bronzo di Barisano daTrani a Ravello: Iconografia e stile, Cava dei Tirreni 1984.

Melczer W., Le porte bronzee di Bonano Pisano, w: Le porte di bronzo dall'antichità al secolo XIII, Roma I990, vol. I, s. 373-387; vol. 2, tab. $335-354$.

Mende U., Kleinbronzen im Umkreis der Magdeburger Gusswerkstatt, w: Der Magdeburger Dom: Ottonische Gründung und staufischer Neubau, Leipzig I989, s. 98-106, il. 26-57.

Mende U., Die Bronzetüren des Mittelalters. 800-I200, München I983.

Morelowski M., Drzwi Gnieźnieńskie, ich zwiazki ze sztuka obca a problem rodzimości, w: Drzwi Gnieźnieńskie, t. I, red. M. Walicki, Wrocław I956, s. $42-100$.

Mossakowski S., La porte de bronze de Gniezno et la „Chronique polonaise” de maître Vincent, „Polish Art Studies” 2 (1980), s. II-29.

Pasierb J. S., Le programme iconographique et iconologique de la Porte de Gniezno, „Polish Art Studies” 2 (1980), s. 3I-49.

Poppe A., Some observations on the bronze doors of the St Sophia in Novogrod, w: Le Pays du Nord et Byzance: Actes du colloque d' Upsal 20-22 avril I979, Upsala I98I, s. 407-4I8.

Roberts H., Izbicki T. M., The fighting figures of Barisano of Trani, „Source” II (I99I), s. 7-I3.

Romańskie Drzwi Płockie II54 - ok. I430-I982, Płock 1983.

Ronchi B., La cattedrale di Trani, Fasano 1986.

Sheppard C. D., The bronze doors of Augsburg Cathedral, w: Hortus imaginum: Studies in western art, Lawrence 1974, s. 21-27, i1. I5-I6.

Sheppard C. D., The bronze doors of Augsburg Cathedral, w: Le porte di bronzo dall'antichità al secolo XIII, Roma I990, vol. I, s. I83-I88; vol. 2, tab. $153-157$. 
Skubiszewski P., L'art. Mosan et la Pologne à l'époque romane: Problématique de recherches, w: Rapports historiques et artistiques entre le Pays mosan et la Pologne, du XIe au début du XIIIe siècle, Liège I98I, s. 27-8I. Skubiszewski P., La porta della cattedrale di Gniezno, w: Le porte di bronzo dall'antichità al secolo XIII, Roma I990, vol. I, S. 247-270; vol. 2, tab. I87-2I2.

Symphosius Amalarius, De ecclesiasticis officiis libri quatuor, w: Theodulfi Aurelianensis episcopi, Sancti Eigilis abbatis Fuldensis, Dungali Reclusi, Ermoldi Nigelli, Symphosii Amalarii presbyteri Metensis Opera omnia [...], accurante J.-P. Migne, Paris I864, k. 935-I242 (Patrologiae Cursus Completus. Series Latina, I05).

Świechowski Z., Sztuka polska: romanizm, Warszawa 2004, s. 303-305.

Walsh D. A., The bronze doors of Barisanus of Trani, w: Le porte di bronzo dall'antichità al secolo XIII, Roma I990, vol. I, s. 399-406; vol. 2, tab. 3OI-373.

Walsh D. A., The iconography of the bronze doors of Barisanus of Trani, „Gesta” 2I (I982) no. 2, s. 9I-IO6.

White J., The bronze doors of Bonanus and the development of dramatic narrative, „Art History” II (I988), s. I58-I94.

Wiliński S., Nad monogramem drzwi gnieźnieńskich, w: Drzwi Gnieźnieńskie, t. I, red. M. Walicki, Wrocław I956, s. IOI-I23.

Zuliani F., La porta bronzea di san Zeno a Verona, w: Le porte di bronzo dall'antichità al secolo XIII, Roma I990, vol. I, s. 407-4I2; vol. 2, tab. $375-388$.

\section{SUMMARY}

\section{The medieval bronze doors and its pictorial cycles as an expression of liturgy: analysis of selected examples}

The principal goal of this paper is to discovery a relationship between pictorial programs of bronze doors of some european churches and the liturgy celebrated in these churches. There is a group of doors, that have been decorated with images representing scenes of Old and New Testament. These are doors from Hildesheim, Verona, Płock and doors made by Bonanus of Pisa - from cathedrale of Pisa and cathedrale of 
Monreale. Its pictorial cycles reveal some balance between images of Old and images of New Testament. On the one hand the Old Testament pictures seems to forecast the events of New Testament. On the other hand the doors of Płock, Piza and Monreale have strictly christological image program, although at the beginning of narative Old Testament elements were also introduced. All these programs are the result of the theological knowledge and sensitivity of clergymen, who designed them at that time. Lech Kalinowski interpreted church doors as a symbole of Christ. However only the alegorical interpetation of liturgy, having its origine in the carolingian culture, can give answer to the question on the relationship between images of doors and liturgy. The course of liturgy and its acts were understood as a recontrsuction of events of Christ's life. So the background of the pictorial, christological cycles of bronze doors was a christological interpretation of the liturgy. However it is not only the matter of presenting the episods of life of Christ, but also of visualization of two mysteries the Mystery of Incarnation and the Mystery of Salvation. The Gniezno door with the life cycle of saint Afdalbert, th doors of Trani and of Ravello, made by Barisanus, where hagiographic and symbolic representations predominate, as well as the door of Augsburg, whose symbolic images make many difficulties in reading them, are the exceptions and special cases. There are considerable difficulties in finding theirs connections to the liturgy celebrated in the church. Therefore they must be researched in a special way in the future 
4. Uniwersytet Papiesk

(T) Jana Pawla II 